Nig. J. Biotech. Vol. 35 (2018) 16-24

ISSN: 01891731

Available online at

http://www.ajol.info/index.php/njb/index

and www.biotechsocietynigeria.org

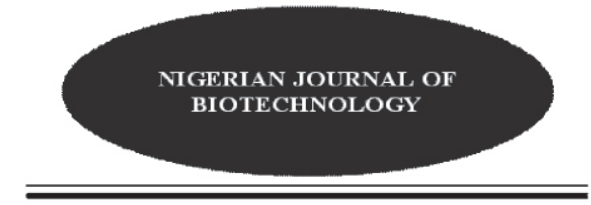

\title{
Optimization of cellulose Production by bacteria isolated from saw dust
}

\author{
${ }^{1}$ Akinleye, H. A., ${ }^{1 *}$ Samuel-Osamoka, F.C. and ${ }^{1}$ Moniloye, H. M. \\ ${ }^{1}$ Department of Microbiology, Federal University Oye-Ekiti, Ekiti State, Nigeria. \\ "Corresponding Author: faith.samuel-osamoka@fuoye.edu.ng

Copyright resides with the authors in terms of the Creative Commons License 4.0.
(See http://creativecommons.org/licenses/by/4.0/).
Condition of use: The user may copy, distribute, transmit and adapt the work, but must recognize
the authors and the Nigerian Journal of Biotechnology.

Abstract

Cellulase enzymes are of enormous value in various industries as well as in treatment of wastes particularly lignocellulosic wastes. This high degree of applications of cellulase necessitates inexhaustible search for more sources of these enzymes. The aim of this study was to optimize the production of cellulase by bacteria from saw dust. Bacteria were isolated from sawdust samples, characterized phenotypically and screened for cellulase production. The production of the enzyme was optimized using different carbon and nitrogen sources, temperature, $\mathrm{pH}$ and lignocellulosic wastes. Five cellulase-producing bacteria were isolated and identified as $\mathrm{A7}_{2}$ and $\mathrm{A7}_{4}$ (Bacillus spp.) $\mathrm{B3}_{2}, \mathrm{~B}_{3}$ and $\mathbf{2 B 5}_{3}$ (Pseudomonas spp.). Two percent (2\%) of carboxymethyl cellulose and $1 \%$ yeast extract gave the highest cellulase production for all the isolates except $\mathbf{A 7}_{2}$ in the case of yeast extract while pH 6.0 was preferred for maximum enzyme production for all except $2 \mathrm{B5}_{3}$ which preferred $\mathrm{pH} 7$. The highest sugar was produced by isolate $2 \mathrm{BS}_{3}(1.38 \pm 0.54 \mathrm{mg} / \mathrm{ml})$ in the presence of sawdust among the lignocellulosic wastes. This study showed that the cellulase produced by these isolates can be used to generate sugar for industrial uses from lignocellulosic wastes and plant origin.

Keywords: Bacteria, Sawdust, Cellulase, Pseudomonas, Bacillus

\section{Introduction}

Lignocellulosic materials are one of the abundant natural complex organic carbons in form of plant biomass, which is highly renewable natural resource in the world (Zhu et. al., 2006). This biomass holds remarkable potential for conversion into commodity products presenting double advantages of sustainable resource supply and environmental quality (Damisa et. al., 2008). The accumulation of lignocellulose wastes causes environmental problems, while the non-use of these materials constitutes a loss of potentially valuable sources (Mishra and
Thakur, 2015). The carbohydrate polymers in lignocellulosic materials need to be converted to simple sugars before fermentation, through a process called hydrolysis (Taherzadeh and Karimi, 2007). Hydrolysis of cellulosic materials is usually by cellulase enzyme complex. The biodegradation of waste materials occurs by the concerted action of various microorganisms which produce a series of enzymes that contribute to the bioconversion process (Pérez et. al., 2002). Cellulose degradation comes from the study of the mesophilic fungi and anaerobic thermophilic cellulolytic bacteria. The bacterial 
cellulases have very high activities against crystalline celluloses like cotton or avicel and are also more thermostable in comparison to fungal cellulases (Rani et. al., 2013). Hence, this study aimed at isolating bacteria with cellulase producing potential and to investigate ability of the isolates in degrading lignocellulosic wastes.

\section{Materials and Methods}

Sample collection

Sawdust samples were collected from Oke gada sawmill in Ede North Local Government, Osun state, Nigeria. The samples were taken from different depths at 5,15,25, 35 and $45 \mathrm{~cm}$ using soil auger, put into different sterile polythene bags and transported to laboratory. The samples were stored at $4^{\circ} \mathrm{C}$ for further analysis.

\section{Isolation of Bacteria}

One gram of sample (sawdust) was added to $10.0 \mathrm{ml}$ sterile distilled water in two different test tubes under aseptic condition. The samples were serially diluted in ten folds. From $10^{-4}, 10^{-6}$ and $10^{-8}, 1.0 \mathrm{ml}$ of each dilution was inoculated onto carboxymethylcellulose agar ( $2.0 \mathrm{~g}$ tryptone, $0.2 \mathrm{~g}$ yeast extract, $0.1 \mathrm{~g} \mathrm{~K}_{2} \mathrm{HPO}_{4}$ and $2.0 \mathrm{~g}$ agar in $200 \mathrm{ml}$ of distilled water) plates using pour plate method. The plates were incubated for 24 hours at $35^{\circ} \mathrm{C}$. Pure cultures of the isolates were obtained by series of subculturing on CMC agar plates.

\section{Characterization of the Isolates}

Pure cultures of the isolates were identified on the basis of colony and cell morphology, Gram staining and biochemical characterization (including Catalase, Oxidase, Triple sugar iron, MRVP, Motility, Spore, $\mathrm{H}_{2} \mathrm{~S}$, Urase, Gelatinase, $\mathrm{NO}_{3}$ reduction and Sugar fermentation tests) as described by Chessbough, (2000) with reference to Bergey's Manual of Systematic Bacteriology (Sneath, 1986).

\section{Cellulase Assay}

Cellulase productions by the isolates were determined using dinitrosalicylic acid (DNSA) reagent method (Immanuel et. al., 2006). Cellulase activity was expressed as amount of enzyme which liberated 1milligram of reducing sugar (glucose equivalent) per millilitre of enzyme solution.

Effect of environmental factors on enzyme production

Various parameters were studied to determine the optimum conditions for enzyme production. These include different concentrations of CMC $(0.5,1.0,1.5$ and $2.0 \%$ $\mathrm{w} / \mathrm{v}) ; 1 \%$ of various nitrogen sources (ammonium sulphate $\left[\left(\mathrm{NH}_{4}\right)_{2} \mathrm{SO}_{4}\right]$, tryptone, yeast extract and urea); Temperature ranges (35, $40,45,50,55$ and $\left.60^{\circ} \mathrm{C}\right)$; $\mathrm{pH}$ ranges $(4,5,6$ and 7.0) and Carbon sources (galactose, lactose, sorbose, sorbitol, glucose and sucrose).

The effects of lignocellulosic substrates (sawdust, Groundnut shell and Corn cob) on cellulase production were also studied. The substrates were alkali-treated by autoclaving the washed and dried lignocellulosic substrates at $121^{\circ} \mathrm{C}$ for $30 \mathrm{mins}$ with $0.25 \mathrm{M} \mathrm{NaOH}(20 \mathrm{ml} / \mathrm{g}$ substrate). The substrates recovered by filtration through muslin cloth were thoroughly washed with deionised water and neutralized with $0.25 \mathrm{M}$ $\mathrm{HCl}$. The substrates were finally washed with many changes of deionized water and dried at 65 ${ }^{0} \mathrm{C}$ to constant weight (Singh et. al., 1988). One gram of each dried substrates was measured as carbon source with $1 \mathrm{~g}$ of tryptone, $0.05 \mathrm{~g}$ of $\mathrm{K}_{2} \mathrm{HPO}_{4}$ and $0.1 \mathrm{~g}$ yeast extract in $100 \mathrm{ml} .10 \mathrm{ml}$ each was dispensed in McCartney bottles and sterilized at $121^{\circ} \mathrm{C}$ for 15 mins. Each bottle was inoculated with $1 \mathrm{ml}$ of $24 \mathrm{~h}$ broth culture of each isolates. The bottles were then incubated at $40^{\circ} \mathrm{C}$ for $1 \mathrm{~h}, 24 \mathrm{~h}, 48 \mathrm{~h}$ and $72 \mathrm{~h}$. The cultures were centrifuged at $4000 \mathrm{rpm}$ for 20 mins. The supernatants were assayed for extracellular cellulase using DNSA reagent method of (Immanuel et. al., 2006).

\section{Results}

Screening for cellulase production: In table 1 , the highest enzyme production on the plates was observed with isolate 2B53 $(1.15 \mathrm{~cm})$ and the least qualitative value of enzyme was obtained with B53 $(0.2 \mathrm{~cm})$. 


\begin{tabular}{ll}
$\mathrm{A} 72$ & 0.30 \\
$\mathrm{~A} 74$ & 0.25 \\
$\mathrm{~B} 32$ & 1.08 \\
$\mathrm{~B} 53$ & 0.2 \\
2B53 & 1.15 \\
\hline
\end{tabular}

Studies on some cultural factors and enzyme production

Effects of different concentrations of CMC on the cellulase production by the isolates

Isolate B32 was found to have the highest cellulase production at concentration of $2.0 \mathrm{w} / \mathrm{v}$ of $\mathrm{CMC}$. The minimum cellulase production for $2 \mathrm{~B} 53$ is at concentration of 0.5 $\mathrm{w} / \mathrm{v}$ when compared to other isolates at the same concentration. Isolate A74 and 2B53 showed substantial increase in cellulase production from $0.5 \mathrm{w} / \mathrm{v}$ and $1.0 \mathrm{w} / \mathrm{v} \mathrm{CMC}$ concentration, while for isolates A72, B32 and B53 the same trend of substantial increase in production was observed from 0.5-2.0 w/v concentrations (Figure 1).

Effects of different Nitrogen sources on the enzyme production by the isolates

The effects of different nitrogen sources on enzyme production of bacterial isolates (A72, A74, B32, B53 and 2B53) was examined in the medium and the results are shown in Figure 2.Only yeast extract produce considerably high amount of enzyme among the nitrogen sources for Pseudomonas spp., 3.31, 1.12 and 2.93 $\mathrm{mg} / \mathrm{ml}$ for B32, B53 and 2B53 respectively.

Effects of different temperatures on the enzyme production by the isolates

In figure 3, A74 showed the highest cellulase production at the temperature of $45^{\circ} \mathrm{C}$ $(0.26 \mathrm{mg} / \mathrm{l})$. Highest cellulase $(0.8 \mathrm{mg} / \mathrm{ml})$ was obtained at $40^{\circ} \mathrm{C}$ by isolate $2 \mathrm{~B} 53$. The enzyme production declined as the temperature increased, A74, B32 and B53 produced the minimal cellulase activity $(0.02 \mathrm{mg} / \mathrm{ml})$ at $60^{\circ} \mathrm{C}$.

Effects of different $\mathrm{pH}$ on and enzyme production by the isolates

In Figure $4 \mathrm{pH} 7$ was found to be favourable for isolate 2B53 for maximal enzyme production whereas, others preferred $\mathrm{pH} 6.0$ to stimulate highest cellulose production apart from A72.

Effects of different Carbon sources on enzyme production

The results obtained showed that different isolates have their most preferred carbon source for enzyme production. For isolate A72 and 2B53 the highest cellulase production was observed in the presence of sucrose $(0.22$ and $0.2 \mathrm{mg} / \mathrm{ml}$ ) while it was glucose for $A 74$ $(0.32 \mathrm{mg} / \mathrm{ml})$, galactose for B32 and B53 (0.24 $\mathrm{mg} / \mathrm{ml})$. The least cellulase production was $A 74$ $(0.02 \mathrm{mg} / \mathrm{ml})$ and in the medium containing lactose.

Effects of different lignocellulosic wastes on the enzyme production by the isolates

Ability of different lignocellulosic wastes to elicit the production of cellulase by the isolates is shown in Table 2. For isolates Bacillus spp.(A72 and A74), the maximum cellulase production was at $24 \mathrm{hr}$ incubation in sawdust and corn cob containing media but $48 \mathrm{hr}$ in ground nut shell. For Pseudomonas sp. (B32), maximum enzyme $(0.46 \mathrm{mg} / \mathrm{ml})$ production was observed at $24 \mathrm{hr}$ incubation in sawdust while it was at $48 \mathrm{hr}$ of incubation for Pseudomonas spp. ( B53 and 2B53) that maximum cellulase $(0.14 \pm 0.01$ and $1.38 \pm 0.54 \mathrm{mg} / \mathrm{ml})$ for B53 and $2 \mathrm{~B} 53$ respectively) production was noticed. For corn cob, the highest values of cellulase production was observed at the $24 \mathrm{hr}$ of incubation for isolates B32 and B53 while there was fluctuations in the amount of the enzyme produced by isolate $2 \mathrm{~B} 53$.

The mean values of cellulase produced at different hours and among the isolates, using various lignocellulosic wastes are shown in Table 2. The statistical significant variations were observed among the quantities of enzyme produced. 

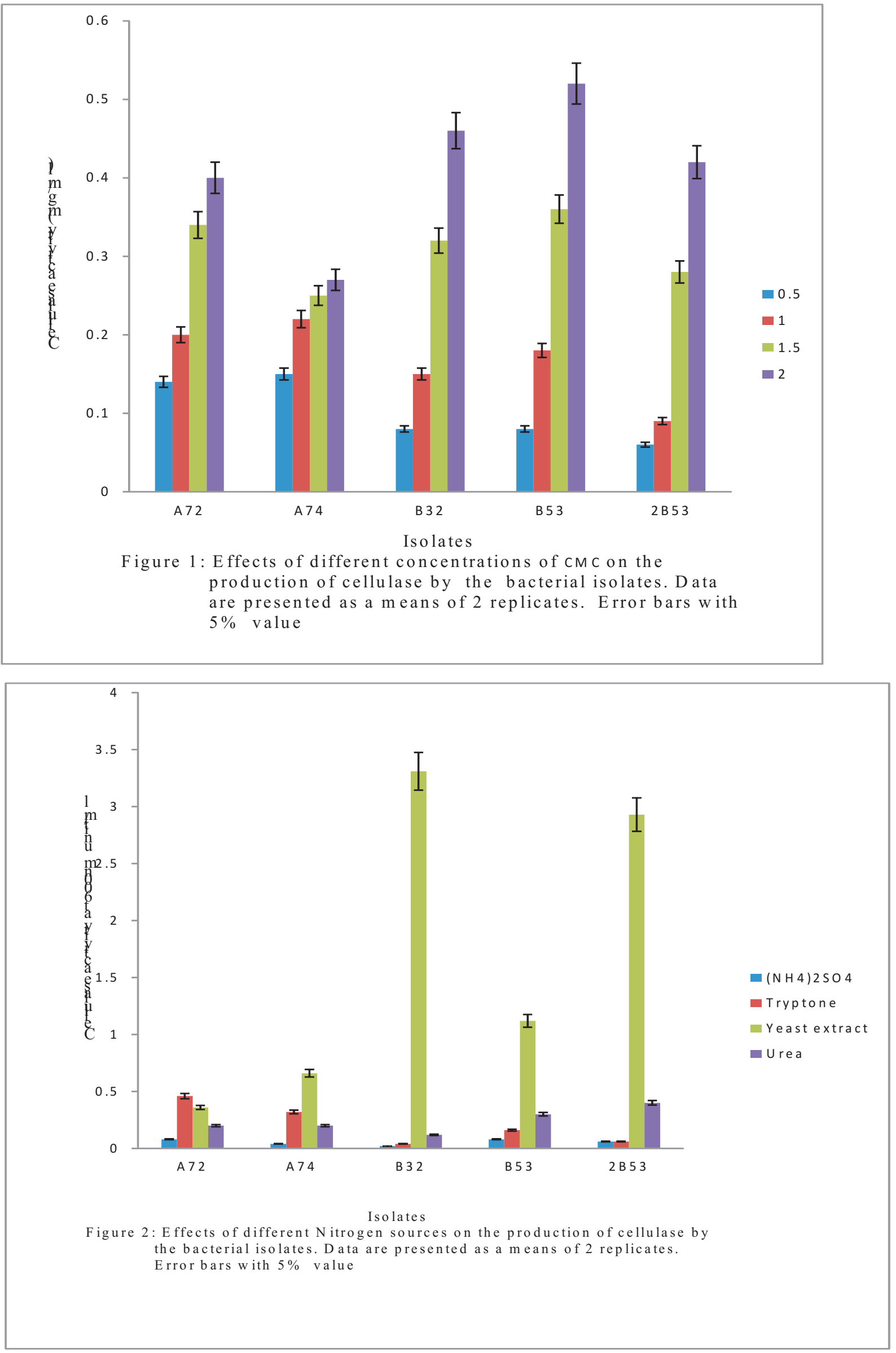

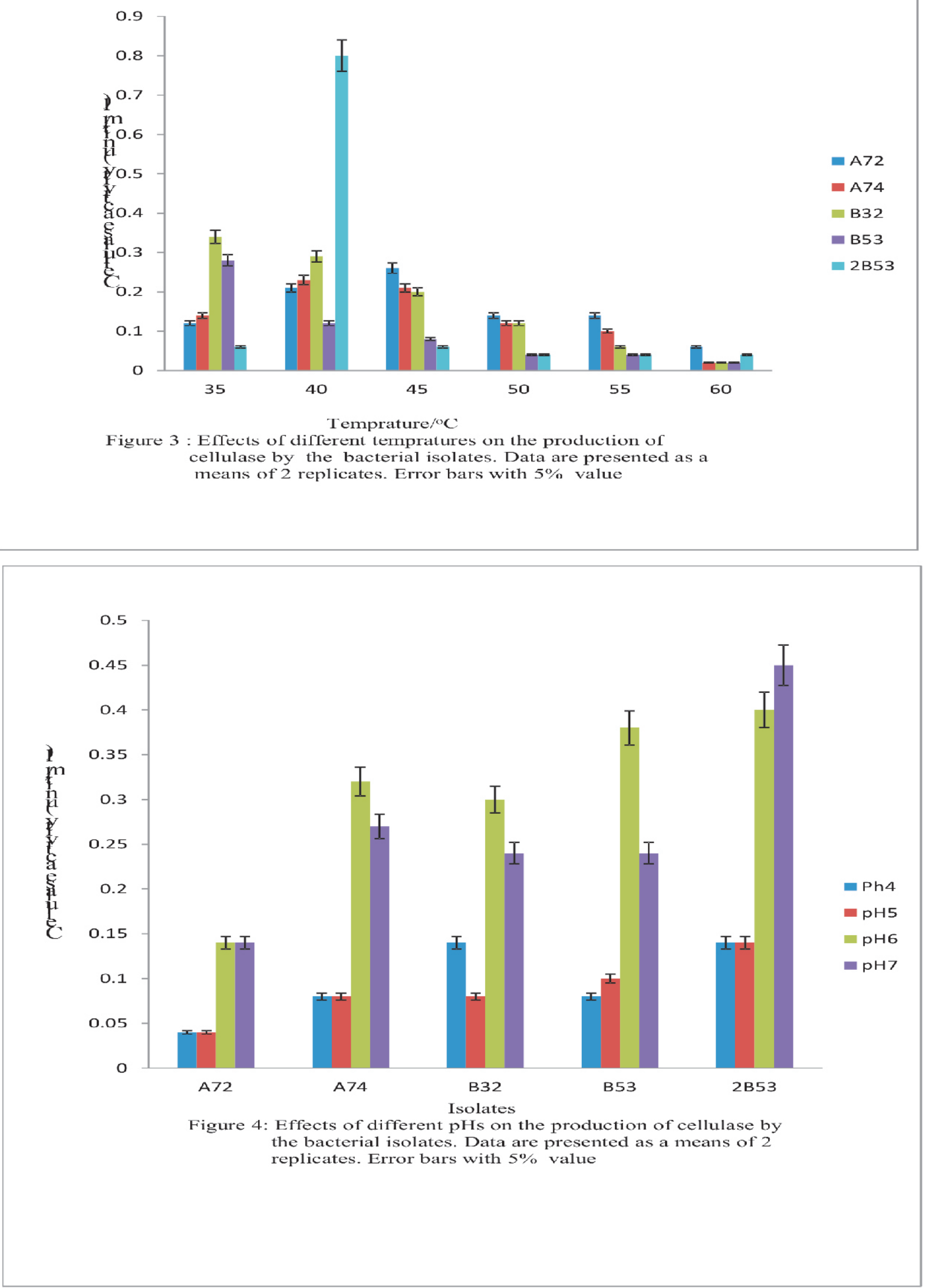


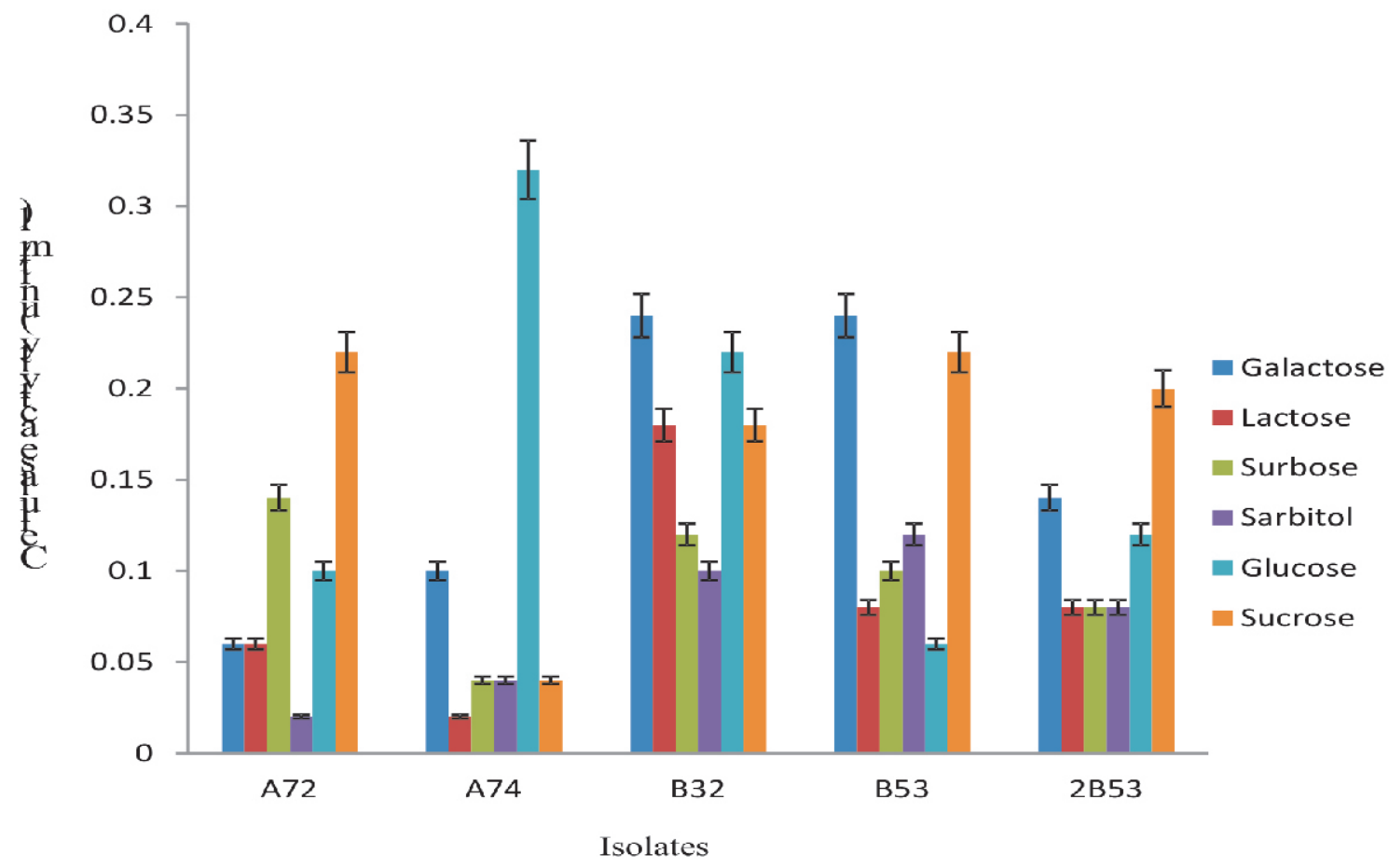

Figure 5: Effects of different carbon sources on the production of cellulase by the bacterial isolates. Data are presented as a means of 2 replicates. Error bars with $5 \%$ valu

Akinyele et al./Nig. J. Biotech. 35 (2018)

Table 2 : Production of cellulase by bacterial isolates through the degradation of lignocellulosic substrates/ Time (hr)

SD GN $\quad$ GC

\begin{tabular}{|c|c|c|c|c|c|c|c|c|c|c|c|c|}
\hline Tsolates/Time(hr) & $\mathrm{Ih}$ & $24 \mathrm{~h}$ & $48 \mathrm{~h}$ & $72 \mathrm{~h}$ & $1 \mathrm{~h}$ & $24 \mathrm{~h}$ & $48 \mathrm{~h}$ & $72 \mathrm{~h}$ & $1 \mathrm{~h}$ & $24 \mathrm{~h}$ & $48 \mathrm{~h}$ & $72 \mathrm{~h}$ \\
\hline A 72 & $0.04 \pm 0.02^{*}$ & $0.36 \pm 0.00^{\mathrm{f}}$ & $0.1=0.00^{4}$ & $0.08 \pm 0.010^{6 t}$ & $0.02 \pm 0.00^{3}$ & $0.06 \pm 0.1^{\mathrm{a}}$ & $0.1 \pm 0.01^{2}$ & $0.1 \pm 0.00^{4}$ & $0.06=0.03^{n}$ & $0.14 \pm 0.01^{*}$ & $0.12 \pm 0.0^{4}$ & $\left.0.1 \pm[.,]^{a}\right]^{a}$ \\
\hline A74 & $0.12=0.03^{\mathrm{b}}$ & $0.46 \pm 0.01^{b}$ & $0.12 \pm 0.03^{a}$ & $0.01 \pm 0.01^{2}$ & $0.12 \pm 0.03^{\mathrm{b}}$ & $0.22 \pm 0.01^{1 t}$ & $0.18 \pm 0.0]^{\mathrm{b}}$ & $0,08 \pm 0,01^{\mathrm{b}}$ & $0.04 \pm 0.00^{4}$ & $0.14 \pm 0.00^{4}$ & $0.14 \pm 0.01^{8}$ & $0.06 \pm 0.01^{\mathrm{b}}$ \\
\hline B32 & $0.12 \pm 0.02^{b}$ & $0.46 \pm 0.011^{b}$ & $012 \pm 0.03^{2}$ & $0.04 \pm 0.03^{\mathrm{a}}$ & $012 \pm 0.02^{b}$ & $0.12 \pm 0.1^{b}$ & $0.16 \pm 0.02^{b}$ & $0.04 \pm 0.12^{\circ}$ & $0.04 \pm 0.000^{4}$ & $0.14 \pm 0.09^{a}$ & $0.10 \pm 0.01^{\mathrm{ab}}$ & $0.04 \pm 0.00^{6}$ \\
\hline B53 & ${ }_{0.06 \pm 0.02^{2 b}}^{0.05 \pm 0.0]^{2}}$ & 0.10 & $\pm 9.61^{\circ}$ & $0.14 \pm 0.01^{\text {को }}$ & $0.08=0.00^{1 \mathrm{x}}$ & $0.16 \pm 0.03^{\circ}$ & ${ }^{c} 0.16 \pm 0.01^{\mathrm{b}}$ & $0.08 \pm 0.01^{b}$ & $0.08=0.53^{\mathrm{ab}}$ & $1.2 \pm 0.03^{\mathrm{E}}$ & $0.4 \pm 0.01^{\mathrm{c}}$ & $\left(.10 \pm 0.00^{\mathrm{a}}\right.$ \\
\hline $2 \mathrm{~B} 53$ & iJ. $16:=0.01^{\text {tb }}$ & $0.16 \pm 0.02^{\mathrm{d}}$ & $1.38 \pm 0.54^{\mathrm{c}}$ & $0.28 \pm 0.5^{\circ}$ & $0.0 \Leftrightarrow \div 0.01^{\circ} 0$ & $0.10 \pm 0.50^{2 \mathrm{de}}$ & $0.14 \pm 0.03^{\mathrm{c}}$ & $0.06 \pm 0.00^{\circ}$ & $0.06 \pm 0.00^{4}$ & $0.06 \pm 0.01^{\mathrm{c}}$ & $0.04 \pm 0.00^{\circ}$ & $0.06 \pm 0.01^{\text {to }}$ \\
\hline
\end{tabular}

SD-Sawdust; CC - Corncob; GS — Groundnut shell. Each value is a mean of two replicates \pm standard deviation among replicates; Means with different letiers within each column differ significantly $(\mathrm{p} \leq 0.05)$ using Duncan's Multiple Range Test 


\section{Discussion}

In this study, extracellular cellulase was produced by bacterial isolates from sawdust. It was discovered that there was a progressive increase in cellulase production by all the isolates from $0.5-2.0 \%$ concentration of CMC. The use of CMC in cellulase production is in agreement with results of Narashima et.al. (2006) who reported high level of cellulase production using cellulose for the growth of Aspergillus and Bacillus spp.

Sources of nitrogen in the medium of growth for an organism are factors in propagation of such isolate. Yeast extract was best utilized by most of the isolates. The same observation was reported by Okeke and Obi, (1993) and Naruma and Jirapa, (2007). This might be due to availability of ready to use amino acid present in yeast extract as compared to other sources of nitrogen used in this study.

Maximum enzyme activity $(0.8 \mathrm{mg} / \mathrm{ml})$ was observed at $40^{\circ} \mathrm{C}$ for isolate $2 \mathrm{~B} 53$ while the minimum yield $(0.02 \mathrm{mg} / \mathrm{ml})$ was noticed at 45 ${ }^{\circ} \mathrm{C}$ for isolate A72. Similar observation had made earlier (Bakare et. al., 2005 and Ray et. al.,2007) for Pseudomonas sp and Bacillus sp.

Highest cellulase production was observed between pH 6.0 and 7.0 for all the isolates. This is in agreement with that of and Annamalai et. al. (2013). The authors reported pH 6.0 to 7.5 for Bacillus sp and Pseudomonas sp enzyme production.

Different isolates have their most preferred carbon source for enzyme production. The least cellulase production was A74 in the medium containing lactose while the highest cellulase production was also from A74 found in the presence of glucose. This report is accordance with Sonla et. al. (2013). Sucrose, glucose and galactose were reported as good carbon sources for cellulase production (Gupta et. al., 2008).

Effect of different lignocellulosic substrates on production of cellulose was investigated. Maximum cellulase production $(1.38 \pm 0.54 \mathrm{mg} / \mathrm{ml})$ was observed for 2B53 at
$48 \mathrm{~h}$ in sawdust medium while the enzyme production $(0.01 \pm 0.01 \mathrm{mg} / \mathrm{ml})$ was recorded for $\mathrm{A} 74$ at $72 \mathrm{hr}$ in the same sawdust medium. The results obtained in this study are consistent with that earlier reported by Ojumu et. al. (2003) and Ja'afaru and Fagade, (2010) that sawdust stimulated cellulase production than other lignocellulosic wastes.

The difference in the production of cellulolytic enzyme on variety of lignocellulosic materials by different organisms might be due to various factors like differences in cellulose content in the lignocellulose obtained from different plant sources, variation in structure and cellulolytic abilities of the organisms at different degree as well as culture conditions (Ja 'afaru and Fagade, 2007; Chinedu et. al., 2011). While Roberto et. al.( 2005) reported the highest production of cellulase and xylanase by Thermoascus auranhticus on corncob. Ojumu et. al. (2003) observed that sawdust gave the best cellulase activity with Aspergillus niger while corncob was the least cellulase producer.

In current study production of enzyme was highest in most cases, within 24-48 hr of incubation. This observation might be due to high concentration of rapidly metabolised carbon source after $24 \mathrm{hr}$ or $48 \mathrm{hr}$ (Chinedu et. al., 2007; Bakri et. al., 2008)

\section{References}

Annamalaia N, Rajeswarib M. V., Elayaraja S and Balasubramanian T. (2013). Thermostable, haloalkaline cellulase from Bacillus halodurans CAS 1 by conversion of Iignocellulosic wastes. DOI: 10.1016/j.carbpol.94(1):409 - 15.

Bakare M. K., AdewaleI. O., Ajayi A., andShonukan O. O.(2005). Purification and characterization of cellulase from the wildtype and two improved mutants of Pseudomonas fluorescens," African J. Biotechnol., 4 (9), 898 $-904$. 
Bakri, U., Jawhar, M. and Arabi, M.I. 2008. Improvement of xylanase production by Cochliobolus sativus in submerged culture. Food. Technol. and Biotechnol.. 46: 116 - 118.

Cheesbrough, M. (2000). District Laboratory Practice in Tropical Countries. Part 2:38 - 39.

Chinedu S. N, Okochi V . I Omidiji O. 2011. Cellulase production by Wild strain of Aspergillus niger, Penicillium chrysogenum and Trichoderma harzianum grown on waste cellulosic materials. Ife J. Sci. 13 (1) 57 - 62

Damisa, D., Ameh, J. B., Umoh V. J. (2008). Effect of chemical pretreatment of some lignocellulosic wastes on the recovery of cellulose from Aspergillus niger AH3 mutant. African J. Biotech. 7 (14) pp 2444 - 2450

Gupta A, Gupta VK, Modi DR (2008). Production and characterization of a-amylase from Aspergillus niger. Biotechnol. 7: 551 - 556.

Immanuel G.,Dhanusha R., Prema P.s and Palavesam A., (2006).Effect of different growth parameters on endoglucanase enzyme activity by bacteria isolated from coir retting effluents of estuarine environment, Int. J. Environ. Sci. and Technol. 3(1):25 - 34 .

Ja`afaru, M. I, Fagade, O. E. 2007. Cellulase production and Enzymatic Hydrolysis of Some Sellected Local Lignocellulosic Sustrates by strain of Aspergillus niger. J. Biol. Res. 2 (1): 13 -16 .

Ja'afaru Mohammed Inuwa and Fagade Obasola Ezekiel, (2010). "Optimization studies on cellulase enzyme production by an isolated strain of Aspergillus niger YL128," African J. Microbiol. Res. 4(24):2635-2639, 18 December.

Mishra, M. and Thakur, I. S. (2015).Biodegradation of Lignocellulosic Waste in the Environment. Adv. Biodegrad. Bioremed. Ind. Waste, 155.

Narashima, G., Sridevi, A.,Buddolla, V., Subhosh, C. M. and Rajasekhar, R. B. (2006).
Nutrient effects on production of cellulolytic enzymes by Aspergillus niger. African J. Biotechnol. 5: 472-476.

Naruma Thongwai and Jipara Panopakarn.(2007). Growth inhibition of RalstoniasolanacearumPT1] by Antogonistic Bacteria isolated from soil in the Northern Part of Thailand. Chiang Mai J. Sci. 34(3): 345 - 354.

Ojumu, T. V., B. O. Solomon, E. Betiku, S. K. Layokun and B. Amigun(2003). Cellulase Production by Aspergillus flavus Linn Isolate NSPR101 fermentedin sawdust, bagasse and corncob." African J. Biotechnol. 2(6): 150 152.

Okeke, B. C. and Obi, S. K. C. (1993). Production of Cellulolytic and Xylanolytic Enzyme by an Arthrographis Species .World. J. Microbiol. Biotechnol. 1;345 - 349.

Pérez, J., J. Muñoz-Dorado, T. de la Rubia, and J. Martínez. (2002). Biodegradation and biological treatments of cellulose, hemicellulose and lignin: an overview. Int. Microbiol. 5:53-63.

Rani, S. R.; Patel, A. K.; Sukumaran, R. K.; Larroche, C., and Pandey, A. (2013). Role and significance of beta-glucosidases in the hydrolysis of cellulose for bioethanol production. Biores.Technol., 127, 500 - 507.

Ray A. K., Bairagi Sarkar A., Ghosh K., and Sen S. K., (2007). "Optimization of fermentation conditions for cellulase production by Bacillus subtilis CY5 and Bacillus circulans TP3 isolated from fish gut," Acta Ichthyologicaet Piscatoria, 37 (1) 47-53.

Roberto da Silva; Ellen S. Lago; Carolina W. Marheb; Maraina M. Macchinone; Yong Kun Park and Eleni Gomes . 2005. Production of xylanase and CMCase on solid state fermentation in different residues by Thermococcus aurantiacus miehe. Brazilian J. Microbiol. 36: 235- 241.

Singh V. K and A. Kumar. 1988. Production and 
Sneath D. H. A. 1986. Bergey's Manual of Systematic Bacteriology, vol2. The Williams and Wikins Co. Baltimore.

Sonla, S., Aparna, D., Gupta, B, and Gupta, S. (2013). Optimization of Cellulase Production from bacteria Isolated from soil, Department of Biotechnology, Dr. B. Lal Institute of Biotechnology, Malviya Industrial Area, Malviya Nagar, Jaipur 302017, India (7), 985 685.
Taherzadeh, M. J. and Karimi, K. (2007).Enzyme based hydrolysis processes for ethanol from lignocellulosic materials: a review. Bio Resources 2:707 - 738.

Zhu, S. Y.; Wu, Z.; Yu, X.; Zhang, H. Li. and Gao, M. (2006): The effect of microwave irradiation on enzymatic hydrolysis of rice straw. Biores. Technol., 97: 1964 - 1968. 